\title{
The effect of a preoperative subconjuntival injection of dexamethasone on blood-retinal barrier breakdown following scleral buckling retinal detachment surgery: a prospective randomized placebo-controlled double blind clinical trial
}

\author{
Ernesto Bali • Eric J. Feron • Ed Peperkamp • \\ Marc Veckeneer • Paul G. Mulder • Jan C. van Meurs
}

Received: 1 October 2009 /Revised: 25 January 2010 /Accepted: 31 January 2010 /Published online: 25 February 2010

(C) The Author(s) 2010. This article is published with open access at Springerlink.com

\begin{abstract}
Background Blood-retinal barrier breakdown secondary to retinal detachment and retinal detachment repair is a factor in the pathogenesis of proliferative vitreoretinopathy (PVR). We wished to investigate whether an estimated 700 to $1000 \mathrm{ng} / \mathrm{ml}$ subretinal dexamethasone concentration at the time of surgery would decrease the blood-retinal barrier breakdown postoperatively.

Methods Prospective, placebo-controlled, double blind clinical trial. In 34 patients with rhegmatogenous retinal detachment scheduled for conventional scleral buckling
\end{abstract}

The authors have no financial relationship with the organisation that sponsored the research (Foundation for Research Rotterdam Eye Hospital-SWOO-Flieringa). The authors have full control of all primary data, and they agree to allow Graefe's Archive for Clinical and Experimental Ophthalmology to review their data upon request.

Clinical Trials registration reference number: ISRCTN (International System of Randomized Controlled Trials Number) 31308983

E. Bali $\cdot$ E. J. Feron · E. Peperkamp · M. Veckeneer

P. G. Mulder · J. C. van Meurs

The Rotterdam Eye Hospital,

Rotterdam, The Netherlands

P. G. Mulder

Department of Biostatistics, Erasmus Medical Center Rotterdam,

Rotterdam, The Netherlands

J. C. van Meurs $(\triangle)$

The Rotterdam Eye Hospital and Erasmus Medical Center,

Schiedamsevest 180 ,

3011 BH Rotterdam, The Netherlands

e-mail: janvanmeurs@cs.com retinal detachment surgery, a subconjunctival injection of $0.5 \mathrm{ml}$ dexamethasone diphosphate $(10 \mathrm{mg})$ or $0.5 \mathrm{ml}$ placebo was given 5-6 hours before surgery. Differences in laser flare photometry (KOWA) measurements taken 1, 3 and 6 weeks after randomisation between dexamethasone and placebo were analysed using mixed model ANOVA, while correcting for the preoperative flare measurement. Results Six patients did not complete the study, one because of recurrent detachment within 1 week, and five because they missed their postoperative laser flare visits. The use of dexamethasone resulted in a statistically significant decrease in laser flare measurements at the 1week postoperative visit.

Conclusion The use of a preoperative subconjunctival injection of dexamethasone decreased 1-week postoperative blood-retina barrier breakdown in patients undergoing conventional scleral buckling retinal detachment surgery. This steroid priming could be useful as a part of a perioperative regime that would aim at decreasing the incidence of PVR.

Keywords Preoperative - Subconjuctival injection . Dexamethasone $\cdot$ PVR $\cdot$ Blood-retina barrier $\cdot$ Breakdown

\section{Introduction}

Proliferative vitreoretinopathy (PVR) remains the major cause of ultimate surgical failure in patients with rhegmatogenous retinal detachment $[9,19]$. Retinal pigment epithelium (RPE) cell dispersion and inflammatory changes secondary to breakdown of the blood-retinal barrier (BRB) 
have been implicated as important pathogenetic mechanisms in the development of PVR [4, 6, 7, 17].

Studies in animals $[5,18]$ have reported that intravitreal corticosteroids may be useful in the prevention of proliferative vitreoretinopathy. Clinical reports have suggested the same effect using either systemic [15] or intravitreal [31] steroids. This was mainly attributed to their attenuating effect on blood-retinal barrier breakdown and their inhibiting effect on proliferation of RPE cells and fibroblasts, which are thought to be transformed RPE cells, and as myofibroblasts responsible for the contractile properties of PVR membranes.

Studies in animals have suggested that pretreating with steroids was more effective in PVR prevention than treatment started at the time of injury or later [5]. Adequate intraocular concentrations of corticosteroids at the time of surgery might reduce the blood-retina barrier breakdown induced by the surgical trauma during cryotherapy, drainage of subretinal fluid, or intravitreal gas injection, and thereby decrease the incidence of PVR.

Weijtens et al. showed in patients that among external routes of administration, a subconjunctival injection of dexamethasone resulted in the highest intravitreal and subretinal fluid concentrations [25, 26, 28-30].

Therefore we wished to study, in patients undergoing conventional scleral buckling retinal detachment surgery, whether a subconjunctival injection of dexamethasone prior to surgery would decrease postoperative blood-retinal barrier breakdown as measured by laser flare photometry.

\section{Materials and methods}

Consecutive patients admitted to the Rotterdam Eye Hospital with a rhegmatogenous retinal detachment scheduled for scleral buckling were included in the study.

Exclusion criteria were therapy with systemic or local steroids, glaucoma, diabetes, and other vascular retinopathies. This prospective, randomized, placebo-controlled, double blind study had been approved by the Institutional Review Board (NRT 194, ISRCTN31308983).

Preoperative investigation All patients underwent a comprehensive ophthalmological examination, including bestcorrected visual acuity tested with an EDTRS chart. Specific items were noted and entered into a database: lens status (phakic or pseudophakic), the presence of vitreous blood, number of quadrants of detached retina, presence and number of horseshoe tears, presence of PVR according to 1983 classification [1], as well as aqueous laser flare meter measurements (Kowa Company, Ltd, Tokyo, Japan). Patients were examined 30 minutes after mydriasis with 5\% phenylephrine and $1 \%$ tropicamide, and always before the application of fluorescein for intraocular pressure measurement. For each eye, five measurements were averaged.

Surgical Technique Six hours before the planned surgery, all patients received under topical anaesthesia (cocaine and oxybuprocaine eye drops) a subconjunctival injection $0.5 \mathrm{ml}$ placebo $\mathrm{NaCl}$ (Delftse Apotheek, Apotheek Westblaak), or $0.5 \mathrm{ml}$ dexamethasone diphosfate $20 \mathrm{mg} / \mathrm{ml}$ (Delftse Apotheek, Apotheek Westblaak). A 30-gauge needle was used, $4 \mathrm{~mm}$ from the limbus, with closure of the injection site by a cottonwool tip for 10 seconds. Randomization had been performed by opening an envelope with study medication that contained either verum or placebo, of which our trial-pharmacist held the code; therefore, surgeons and technicians alike were blinded to the nature of the subconjunctival injection. All patients underwent a standard scleral buckling procedure as described before [22, 23]. A silicone band was placed under the four rectus muscles at the presumed area of the vitreous base, and the sclera under retinal tears and breaks was indented with either a circumferential (278, 277, 287 Mira Silastic) or radial (7.5 mm sponge) buckle. Subretinal fluid was drained in all patients. Retinopexy of the tears or breaks was done by cryocoagulation during surgery, or with an argon laser mounted on a slit lamp between 2 and 6 weeks after the surgery, according to the surgeons' preference. In some patients, an air or gas (air/SF6) tamponade was used. All patients received a $2 \mathrm{mg}$ dexamethasone and $1 \mathrm{mg}$ gentamycin subconjunctival injection at the end of the surgery.

Follow-up All patients received the same postoperative treatment, prednisolone acetate $1 \%$ eyedrops in a tapering dose over 6 weeks. ETDRS vision, a fundus exam and laser flare measurements were taken at 1, 3 and 6 weeks.

The treatment effects of dexamethasone versus placebo on flare were analyzed after logarithmic transformation of flare (photon counts $/ \mathrm{ms}$ ). Hence, effects were specified as percentage differences in photon counts $/ \mathrm{ms}$. Mixed model ANOVA was used to estimate and test for statistical significance the effects on flare of week (weeks 1, 3 and 6), treatment (dexamethasone, placebo), and their interaction. The baseline measurement of flare at week 0 was entered as covariable in the model, along with its interaction with week. No structure was imposed on the (co)variances of the three repeated measurement of flare.

\section{Results}

A total of 34 patients (19 males/ 15 females) were included from 1 February 2003 to 1 February 2004. The age of the 
patients ranged from 18 to 76 years (mean 54 years). Follow-up ranged from 6 to 8 months. Six patients did not complete the study as planned. One patient had a redetachment due to an undetected tear within the first weeks, and five patients missed two or more of their laser flare followup visits; none of these five patients suffered new breaks or a redetachment.

Of the remaining patients, 15 were in the placebo group and 13 in the dexamethasone group. The various baseline characteristics, such as preop vision, macula on or off, quadrants involved, type of breaks, or variables depending on the surgical procedure such as cryocoagulation or postoperative laser, were equally distributed between the dexamethasone-treated patients and the placebo group (Table 1). At the last examination, two patients given placebo and two patients given dexamethasone had an intraocular pressure between 20 and $25 \mathrm{mmHg}$.

In the placebo group, laser flare measurements on average increased during the first week and decreased thereafter. In the dexamethasone group, there was a steady decrease as from week 0 (Table 2, summary raw data). The mixed model ANOVA yielded the following results. The treatment effect on flare of dexamethasone versus placebo differed significantly between the three weeks $(P=0.007)$.

Table 1 Baseline characteristics of the two groups

\begin{tabular}{|c|c|c|c|c|c|c|c|c|c|c|c|c|}
\hline & Age & Refr & IOL & Preop vision & Preop PVR & Macula & Quadrants & Holes & Horseshoe tears & Surgeon & Laser & Cryo \\
\hline \multicolumn{13}{|c|}{ Dexa patients } \\
\hline 1 & 65 & plan & & 0.016 & & off & 3 & & 1 & $\mathrm{E}$ & $\mathrm{x}$ & \\
\hline 2 & 21 & plan & & 1.6 & & on & 2 & 1 & & $\mathrm{C}$ & $\mathrm{x}$ & \\
\hline 3 & 44 & $\mathrm{nn}$ & & 0.1 & & off & 2 & & 2 & B & & $\mathrm{x}$ \\
\hline 4 & 72 & plan & & 0.003 & & off & 2 & & 2 & $\mathrm{C}$ & $\mathrm{x}$ & \\
\hline 5 & 60 & -5 & & 0.25 & & off & 1 & & 1 & $\mathrm{D}$ & & \\
\hline 6 & 56 & -5 & & 0.016 & & off & 2 & 1 & & $\mathrm{D}$ & $\mathrm{x}$ & \\
\hline 7 & 66 & plan & & 0.016 & & off & 2 & 1 & & $\mathrm{D}$ & & $\mathrm{x}$ \\
\hline 8 & 40 & -3 & & 0.016 & & off & 2 & 2 & & $\mathrm{C}$ & $\mathrm{x}$ & \\
\hline 9 & 47 & -10 & & 1.0 & & on & 1 & 1 & & $\mathrm{D}$ & $\mathrm{x}$ & \\
\hline 10 & 71 & -3 & + & 0.003 & & off & 3 & & 2 & B & & $\mathrm{x}$ \\
\hline 11 & 49 & -9 & & 0.15 & & off & 1 & 1 & & $\mathrm{E}$ & & $\mathrm{x}$ \\
\hline 12 & 65 & $\mathrm{nn}$ & & 0.25 & & off & 2 & & 1 & $\mathrm{D}$ & $\mathrm{x}$ & \\
\hline 13 & 81 & plan & & 0.7 & A & on & 2 & 1 & & $\mathrm{C}$ & $\mathrm{x}$ & \\
\hline \multicolumn{13}{|c|}{ Placebo patients } \\
\hline 1 & 77 & -2 & & 0.003 & & off & 3 & & & $\mathrm{E}$ & & $\mathrm{x}$ \\
\hline 2 & 55 & plan & & 0.016 & & off & 3 & & 1 & $\mathrm{C}$ & $\mathrm{x}$ & \\
\hline 3 & 61 & -4 & & 1.0 & & on & 1 & & 1 & $\mathrm{D}$ & $\mathrm{x}$ & \\
\hline 4 & 47 & -6 & & 1.0 & & on & 1 & 1 & & $\mathrm{E}$ & & $\mathrm{x}$ \\
\hline 5 & 29 & -3 & & 0.25 & A & off & 1 & 2 & & $\mathrm{C}$ & $\mathrm{x}$ & \\
\hline 6 & 59 & -8 & & 1.0 & & on & 1 & & 1 & $\mathrm{~B}$ & & $\mathrm{x}$ \\
\hline 7 & 40 & -.7 & & 0.7 & & part & 2 & 1 & & $\mathrm{D}$ & $\mathrm{x}$ & \\
\hline 8 & 64 & plan & & 0.003 & $\mathrm{C} 1$ & off & 2 & & 1 & B & & $\mathrm{x}$ \\
\hline 9 & 56 & -5 & & 0.003 & & off & 2 & & 1 & $\mathrm{C}$ & $\mathrm{x}$ & \\
\hline 10 & 62 & -6 & & 0.003 & & off & 2 & & 1 & $\mathrm{C}$ & $\mathrm{x}$ & \\
\hline 11 & 17 & plan & & 0.6 & & part & 1 & & dialysis & $\mathrm{D}$ & & $\mathrm{x}$ \\
\hline 12 & 30 & +2 & & 0.5 & & part & 1 & & 1 & B & & $\mathrm{x}$ \\
\hline 13 & 59 & -7 & & 1.0 & & on & 1 & & 1 & B & & $\mathrm{x}$ \\
\hline 14 & 71 & $\mathrm{nn}$ & & 0.1 & & off & 2 & 2 & & & $\mathrm{x}$ & \\
\hline 15 & 22 & -6 & & 1.0 & & on & 1 & 1 & & A & $\mathrm{x}$ & \\
\hline
\end{tabular}

refr: refractive error

plan: plano refraction

IOL: intraocular lens

nn: not noted

part: partially off/partially attached 
Table 2 Laser flare measurements (counts per seconds) at four visits, and their relative percentage in patients treated with dexamethasone when compared to patients treated with placebo

\begin{tabular}{|c|c|c|c|c|c|c|c|c|}
\hline \multirow[t]{2}{*}{ Week } & \multirow[t]{2}{*}{ Treatment } & \multicolumn{4}{|c|}{ Summary raw data } & \multicolumn{3}{|c|}{ Mixed model ANOVA estimates } \\
\hline & & $N$ & Median & Min. & Max. & $\%$ dexa vs placebo & $95 \% \mathrm{CI}$ & $P$-value \\
\hline \multirow[t]{2}{*}{0} & Placebo & 16 & 10.2 & 2.4 & 94.0 & & & \\
\hline & Dexa & 13 & 10.4 & 7.7 & 95.6 & & & \\
\hline \multirow[t]{2}{*}{1} & Placebo & 16 & 16.7 & 3.1 & 56.9 & & & \\
\hline & Dexa & 12 & 8.1 & 1.0 & 58.6 & $-48.3 \%$ & $-72.1 \%$ to $-4.4 \%$ & 0.017 \\
\hline \multirow[t]{2}{*}{3} & Placebo & 15 & 9.6 & 2.2 & 16.1 & & & \\
\hline & Dexa & 12 & 7.1 & 3.1 & 48.9 & $+2 \%$ & $-37.8 \%$ to $+67.2 \%$ & 0.94 \\
\hline \multirow[t]{2}{*}{6} & Placebo & 15 & 5.7 & 0.9 & 14.0 & & & \\
\hline & Dexa & 12 & 6.2 & 1.6 & 12.4 & $+17.6 \%$ & $-35.1 \%$ to $+113 \%$ & 0.58 \\
\hline
\end{tabular}

The effect of baseline flare on flare during treatment also decreased significantly across the 3 weeks $(P=0.019)$. Only at week 1 was a significant reduction of dexamethasone relatively to placebo seen: flare was $48.3 \%$ lower under dexamethasone, adjusted for baseline flare (95\% CI: $72.1 \%$ lower to $4.4 \%$ lower; $P=0.037$ ); see the mixed model ANOVA estimates in Table 2.

\section{Discussion}

Intravitreal dexamethasone has been shown to reduce the number of tractional detachments in experimental animal models of PVR by cell-injection [18, 20]. Studies in animals and patient have suggested that pretreating with steroids was more effective in PVR prevention than treatment started at the time of injury or later [5]. It was speculated that the decrease of BRB breakdown and inhibition of the proliferation of RPE cells accounted for this effect. Dexamethasone has a biphasic effect on RPE cell proliferation in vitro, i.e. rather a stimulatory effect with lower concentrations (ng per ml) [12, 32, 33], and an inhibitory effect on proliferation of RPE in vitro at relatively high concentrations ( $\mathrm{mg}$ per $\mathrm{ml}$, not reached by peribulbar or systemic administration, only by intravitreal injection).

Corticosteroids bind to intracellular receptors and act on inflammation by inhibiting the synthesis of immunoregulatory proteins such as cytokines. The magnitude of this response is directly proportional to the number of occupied steroid receptors and is therefore dose-dependant [3]. Given the studies by Weijtens et al. in patients with rhegmotogenous retinal detachments, macular puckers and macular holes, which showed that a subconjunctival dexamethasone injection would result in optimal concentrations in the vitreous (72.5 $\mathrm{ng} / \mathrm{ml}$ after $2.5 \mathrm{mg}$ dexamethasone [25]) and the subretinal fluid $(367 \mathrm{ng} / \mathrm{ml}$ after $2.5 \mathrm{mg}$ dexamethasone
[27]) between 3 and 6 hours after injection; and assuming that the time interval between binding to the steroid receptor and transcription of effector proteins would take less than 2 hours, we timed the subconjunctival injection 5 to 6 hours before surgery. It may well be that only direct steroid-receptor ligand prevention of nuclear factor kappa B pro-inflammatory effect is acting within this time interval [8]. The estimated dexamethasone concentration levels of 700 to $1000 \mathrm{ng} / \mathrm{ml}$ reached with our injection would be effective in decreasing BRB by inducing tight-junction formation [2] and the modulation of cytokine release[11], but not for cell growth inhibition [12, 16, 32, 33].

The disadvantage of using dexamethasone is its short half-life, limiting the time interval in which the drug can be used to minimize the surgically induced inflammation. For clinical purposes, a longer-acting steroid would allow a more flexible preoperative administration treatment moment, as well as a longer treatment effect, but it would be at the price of a higher incidence of raised intraocular pressure and a lower subretinal and vitreous concentration at the time of surgery. To ensure a continuous affective steroid concentration following preoperative priming by a subconjunctival dexamethasone injection, pre-operative intravitreal injection of longer-acting triamcinolone, or a sustained release implant might be an feasible option [14, 34].

A drawback of our study was the small number of patients enrolled. By changes in admission policy right at the start of our study, patients were no longer admitted the day before surgery but were treated on an ambulatory basis. Potential study patients were asked to come in at least 6 hours earlier then the normal admission time, which was a significant inconvenience and reduced the number of patients willing to participate in the study. Therefore, we could only use a quantitative surrogate marker, i.e. laser flare, as a measurement of BRB breakdown, instead of the originally intended rate of PVR. 
Laser flare photometry, however, allows precise and non-invasve quantification of the aqueous protein content. Although laser flare photometry has been used mainly to study anterior segment inflammation, it has been shown to be useful in monitoring posterior segment disease $[10,13$, $21,23,24]$.

This study showed that a single injection of dexamethasone, injected at an estimated optimized time interval preoperatively, significantly decreased bloodretinal barrier breakdown at 1 week induced by a scleral buckling procedure. We cannot exclude, however, that a similar effect would have been achieved by supplying the same dose at the time of surgery or with a longer interval before surgery. To answer that comprehensively, a four-armed study would have been necessary. Nevertheless, our findings may help in designing a feasible, optimal perioperative steroid regime, which might include a sustained release device or intravitreal injection at the end of conventional surgery or, in the case that vitrectomy is chosen to treat the retinal detachment, steroids in the peroperative intravitreal infusion. However, surgically induced inflammation is only one risk factor among others in the development of PVR. Larger studies including greater numbers of patients, a more sustained dexamethasone regime, and longer follow-up are needed to demonstrate whether pharmacologically decreasing the blood-retina barrier breakdown ultimately may lead to a lower incidence of PVR.

Open Access This article is distributed under the terms of the Creative Commons Attribution Noncommercial License which permits any noncommercial use, distribution, and reproduction in any medium, provided the original author(s) and source are credited.

\section{Reference}

1. The Retina Society Terminology Committee (1983) The classification of retinal detachment with proliferative vitreoretinopathy. Ophthalmology 90(2):121-125

2. Antonetti DA, Wolpert EB, DeMaio L, Harhaj NS, Scaduto RC Jr (2002) Hydrocortisone decreases retinal endothelial cell water and solute flux coincident with increased content and decreased phosphorylation of occludin. J Neurochem 80(4):667-677

3. Barnes PJ (1995) Anti-inflammatory mechanisms of glucocorticoids. Biochem Soc Trans 23(4):940-945

4. Campochiaro PA (1997) Pathogenic mechanisms in proliferative vitreoretinopathy. Arch Ophthalmol 115(2):237-241

5. Chandler DB, Hida T, Sheta S, Proia AD, Machemer R (1987) Improvement in efficacy of corticosteroid therapy in an animal model of proliferative vitreoretinopathy by pretreatment. Graefes Arch Clin Exp Ophthalmol 225(4):259-265

6. Charteris DG, Hiscott P, Grierson I, Lightman SL (1992) Proliferative vitreoretinopathy. Lymphocytes in epiretinal membranes. Ophthalmology 99(9):1364-1367
7. Charteris DG, Hiscott P, Robey HL, Gregor ZJ, Lightman SL, Grierson I (1993) Inflammatory cells in proliferative vitreoretinopathy subretinal membranes. Ophthalmology 100(1):43-46

8. Felinski EA, Antonetti DA (2005) Glucocorticoid regulation of endothelial cell tight junction gene expression: novel treatments for diabetic retinopathy. Curr Eye Res 30(11):949-957

9. Girard P, Mimoun G, Karpouzas I, Montefiore G (1994) Clinical risk factors for proliferative vitreoretinopathy after retinal detachment surgery. Retina 14(5):417-424

10. Guex-Crosier Y, Pittet N, Herbort CP (1995) Sensitivity of laser flare photometry to monitor inflammation in uveitis of the posterior segment. Ophthalmology 102(4):613-621

11. Han QH, Hui YN, Du HJ, Zhang WJ, Ma JX, Wang SY (2001) Migration of retinal pigment epithelial cells in vitro modulated by monocyte chemotactic protein-1: enhancement and inhibition. Graefes Arch Clin Exp Ophthalmol 239(7):531-538

12. He S, Wang HM, Ye J, Ogden TE, Ryan SJ, Hinton DR (1994) Dexamethasone induced proliferation of cultured retinal pigment epithelial cells. Curr Eye Res 13(4):257-261

13. Herbort CP, Guex-Crosier Y, de Ancos E, Pittet N (1997) Use of laser flare photometry to assess and monitor inflammation in uveitis. Ophthalmology 104(1):64-71

14. Jaffe GJ, Martin D, Callanan D, Pearson PA, Levy B, Comstock T (2006) Fluocinolone acetonide implant (Retisert) for noninfectious posterior uveitis: thirty-four-week results of a multicenter randomized clinical study. Ophthalmology 113(6):1020-1027

15. Koerner F, Merz A, Gloor B, Wagner E (1982) Postoperative retinal fibrosis - a controlled clinical study of systemic steroid therapy. Graefes Arch Clin Exp Ophthalmol 219(6):268-271

16. Nehme A, Edelman J (2008) Dexamethasone inhibits high glucose-, TNF-alpha-, and IL-1beta-induced secretion of inflammatory and angiogenic mediators from retinal microvascular pericytes. Invest Ophthalmol Vis Sci 49(5):2030-2038

17. Pastor JC, De La Rua ER, Martin F (2002) Proliferative vitreoretinopathy: risk factors and pathobiology. Prog Retin Eye Res 21(1):127-144

18. Pastor JC, Rodriguez E, Marcos MA, Lopez MI (2000) Combined pharmacologic therapy in a rabbit model of proliferative vitreoretinopathy (PVR). Ophthalmic Res 32(1):25-29

19. Rachal WF, Burton TC (1979) Changing concepts of failures after retinal detachment surgery. Arch Ophthalmol 97(3):480-483

20. Tano Y, Chandler D, Machemer R (1980) Treatment of intraocular proliferation with intravitreal injection of triamcinolone acetonide. Am J Ophthalmol 90(6):810-816

21. Tugal-Tutkun I, Cingu K, Kir N, Yeniad B, Urgancioglu M, Gul A (2008) Use of laser flare-cell photometry to quantify intraocular inflammation in patients with Behcet uveitis. Graefes Arch Clin Exp Ophthalmol 246(8):1169-1177

22. Van Meurs JC, Feron E, van Ruyven R, Mulder P, Veckeneer M (2002) Postoperative laser coagulation as retinopexy in patients with rhegmatogenous retinal detachment treated with scleral buckling surgery: a prospective clinical study. Retina 22(6):733739

23. Veckeneer M, van Overdam K, Bouwens D, Feron E, Mertens D, Peperkamp E, Ringens P, Mulder P, Van Meurs J (2001) Randomized clinical trial of cryotherapy versus laser photocoagulation for retinopexy in conventional retinal detachment surgery. Am J Ophthalmol 132(3):343-347

24. Watanabe $\mathrm{K}$, Ideta $\mathrm{H}$, Nakatake J, Shinagawa K, Demizu S, Takenaka C (1995) Anterior chamber inflammation after transconjunctival cryosurgery. Graefes Arch Clin Exp Ophthalmol 233 (2):71-73

25. Weijtens O, Feron EJ, Schoemaker RC, Cohen AF, Lentjes EG, Romijn FP, Van Meurs JC (1999) High concentration of dexamethasone in aqueous and vitreous after subconjunctival injection. Am J Ophthalmol 128(2):192-197 
26. Weijtens O, Schoemaker RC, Cohen AF, Romijn FP, Lentjes EG, van Rooij J, Van Meurs JC (1998) Dexamethasone concentration in vitreous and serum after oral administration. Am J Ophthalmol 125(5):673-679

27. Weijtens O, Schoemaker RC, Lentjes EG, Romijn FP, Cohen AF, Van Meurs JC (2000) Dexamethasone concentration in the subretinal fluid after a subconjunctival injection, a peribulbar injection, or an oral dose. Ophthalmology 107(10):1932-1938

28. Weijtens O, Schoemaker RC, Lentjes EG, Romijn FP, Cohen AF, Van Meurs JC (2000) Dexamethasone concentration in the subretinal fluid after a subconjunctival injection, a peribulbar injection, or an oral dose. Ophthalmology 107(10):1932-1938

29. Weijtens O, Schoemaker RC, Romijn FP, Cohen AF, Lentjes EG, Van Meurs JC (2002) Intraocular penetration and systemic absorption after topical application of dexamethasone disodium phosphate. Ophthalmology 109(10):1887-1891

30. Weijtens O, van der Sluijs FA, Schoemaker RC, Lentjes EG, Cohen AF, Romijn FP, Van Meurs JC (1997) Peribulbar corticosteroid injection: vitreal and serum concentrations after dexamethasone disodium phosphate injection. Am J Ophthalmol 123(3):358-363

31. Williams RG, Chang S, Comaratta MR, Simoni G (1996) Does the presence of heparin and dexamethasone in the vitrectomy infusate reduce reproliferation in proliferative vitreoretinopathy? Graefes Arch Clin Exp Ophthalmol 234(8):496-503

32. Wu WC, Kao YH, Hu DN (2002) A comparative study of effects of antiproliferative drugs on human retinal pigment epithelial cells in vitro. J Ocul Pharmacol Ther 18(3):251-264

33. Wu WC, Kao YH, Tseng HY (2003) The cell cycle distribution of cultured human retinal pigmented epithelial cells under exposure of anti-proliferative drugs. J Ocul Pharmacol Ther 19 (1):83-90

34. Zhou T, Lewis H, Foster RE, Schwendeman SP (1998) Development of a multiple-drug delivery implant for intraocular management of proliferative vitreoretinopathy. J Control Release 55(23):281-295 